\title{
A STUDY TO ASSESS THE IMPACT OF NARCISSIST PERSONALITY FACTORS IN COSMETIC ADVERTISING AMONG YOUTH IN BANGALORE CITY
}

\author{
Syed Kazim
}

Associate Professor, Acharya Bangalore B School (ABBS), Bengaluru, Karnataka, India.

\section{V.P. Sriram}

Associate Professor, Acharya Bangalore B School (ABBS), Bengaluru, Karnataka, India.

\section{Dattatreya Reddy Peram}

Assistant Professor, Acharya Bangalore B School (ABBS), Bengaluru, Karnataka, India.

\begin{abstract}
The research paper aims to find the demographic profiles of cosmetic users, to identify the factors of Narcissist Personality, to find out the bond relationship exists between the dependent variable 'Influence of Cosmetic Advertisements 'with that of the Independent Variables related to that of Narcissist Personality and to identify the impact of 'Narcissist Personality Factors' on 'Influence of Cosmetic Advertisements'. The research was conducted in the Bengaluru City of Karnataka State, India. The primary data was collected among the Youth residing in Bengaluru. The aim of the research is to see how the personality of the youth is affected when he views the cosmetic advertisements. Data is collected from Youth who are residing in different parts of Bengaluru. The outcome of the study would reveal as to how the narcissist personality factors have an impact on Youth who view cosmetic advertisements. The study would help policy makers, government, cosmetic companies, research agencies and advertisements companies to take better and well informed decisions in the future. The study will be of great help to the youth and business fraternity and society as a whole.
\end{abstract}

Key words: Narcissist, Personality, Cosmetic, Advertising, Youth.

Cite this Article: Syed Kazim, V.P. Sriram, Dattatreya Reddy Peram, A Study to Assess the Impact of Narcissist Personality Factors in Cosmetic Advertising Among Youth in Bangalore City, International Journal of Management, 11(12), 2020, pp 1689-1699. http://iaeme.com/Home/issue/IJM?Volume=11\&Issue=12 


\section{INTRODUCTION}

In the Global Business Environment, The cosmetics industry expected to register a drastic and vigorous annual growth of $25 \%$ by reaching a milestone of USD 22 billion by the end of 2025 . Increasing awareness about various beauty products has brought a greater change in consumption patterns and lifestyles among the individuals across different demographic profiles and it has in turn improved purchasing capability and power among both men and women are expected to boost the industry to grow in a rapid fast manner. In the Global Cosmetic business environment, the market started with healthy growth and in turn it certainly maintains its momentum to a certain level. There was a due growth because of rising preference towards specialized products. [1]

Narcissist Personality Disorder is a personality disorder where the individual gains excessive interest of oneself and one's physical appearance. It is a form of pleasure that that leads to admiring and appreciating one's own self. The person goes on be become a more selfish human being, where he at a later stage begins to admire and appreciating his own skills, talents, capabilities, etc. The individual begins to feel that he is special and unique. In short, in this type of personality, the individual falls in love with himself.

\section{STATEMENT OF THE PROBLEM}

Demand for skin whitening products for women and men are driving the trend for cosmetic products but other beauty products are not far behind. Companies like Lakme, Revlon, L'Oreal, Unilever, Shahnaz Husain, Maybelline, Elle 18, etc., top the list in this segment. These companies have played a significant role in promoting the seemingly magical lightening qualities of their products in universal advertising. Thus, companies in India are putting every effort to sell their products with the help of massive advertising every day. Due to these cosmetic advertisements, the customers are having a more of a negative impact than having a positive impact, as they become more self-conscious and materialistic. Thus, is the need of the hour to study the impact of cosmetic advertisements on the personality traits of the youth and their influence?

Personality traits results in predispositions. They result in attitude of the consumer which in turn influences purchase intention and search evaluation. Advertising is one of the key factors in impressing on consumer attitude, or purchase intention. The research tries to find out the influence of cosmetic advertising on purchase intention, specifically among the youth in Bengaluru. The study specifically tries to find how whether advertisements have been able to influence Consumer Personality and thereby purchase intention among the youth of Bengaluru, the select research area.

\section{MAJOR OBJECTIVES OF THE RESEARCH}

- To find the demographic profiles of cosmetic users.

- To identify the factors of Narcissist Personality.

- To find out the bond relationship exists between the dependent variable 'Influence of Cosmetic Advertisements' with that of the Independent Variables related to that of Narcissist Personality.

- To identify the impact of 'Narcissist Personality Factors' on 'Influence of Cosmetic Advertisements'.

\section{REVIEW OF LITERATURE}

Advertisements might not give instant result; it affects the thinking and mind-set of the consumers and has an impact in the long run. With the increase in population across the country, 
it is necessary the firms allocate a decent among in the annual budget for advertisements and all other activities which are associated with it. This will surely have a positive impact on the sale of cosmetic products [3].

Studies on consumers help us understand the nature of consumers' intention. Researchers have adopted various methods to analyze and investigate the behaviour and intention and behaviour. Various sophisticated tolls which are provided by behavioral sciences have been employed to understand and predict the behaviour of people in the most effective fashion. Various disciplines such as sociology, socio-psychology and psychology are employed in this regard. In order to develop a framework to understand consumer intention, it is necessary to learn as to how there has been an evolution to understand consumers and what research has taken place in the past to understand how consumers tend to behave and understand. It should be known about the different paradigms which are employed in this regard. When we try to see the research on consumers, it can basically be classified based on certain assumptions about what and how the researcher is going to study the problem [2]. When they see the relationship between the aggregated consumption with advertising expenses, with the help of a model, which explains that, a relationship exists between the factors. From this it was concluded that consumption and advertising have strong relationship between one another [4].

The perception toward the cosmetics advertisements is explained well with respect to change in the consumer behaviour with reference to impact of a particular advertisement. Various ineffective elements reflect the emotions which are aroused after viewing the respective advertisement and a particular component which is cognitive, which ultimately reflects how effective was the message and the information [5]. Adornments are of different kinds such as, cosmetics, clothes, jewellery, etc. Among them all, the most impactful are cosmetics. When compared to jewellery and clothes, cosmetics are the products which are of the least price and are products which needs to be purchased more frequently when compared to jewellery and clothes, this is because jewellery is some one-time purchase and clothes are purchased one in while, say once or twice in a year. The study basically revealed that the people with low selfesteem and who feel they are unattractive will heavily depend on using cosmetics for their adornment [6].

The consumers' intention mainly influences three basic aspects, such as, acquiring, using and disposing. With respect to acquiring, it refers to how the consumers are spending their money on products. With respect to using, it refers to as how high-priced products, sees the quality in it. And finally, with respect to distribution, it refers to how to place a particular product [7][8].Among various aspect which are significant for cosmetics companies, the most important of them all is brand loyalty. When consumers have high level of brand loyalty then would come back again and again and purchase cosmetics of the same brand. But, in the current scenario it has become very difficult to sustain the loyalty of the consumers and also in the present situation it would be very difficult to predict the buyer behaviour [9][10].

\section{RESEARCH METHODOLOGY}

\subsection{Sampling Design}

Among the entire country, all metro cities top the list with respect to sale of cosmetics. Among all the metro cities, Bengaluru had the fastest growth with respect to sale of cosmetics, in the last five years according to 'Loreal' (one of the most popular brand of cosmetics). Bruhat Bengaluru Mahanagara Palike (BBMP) has divided Bengaluru into ten zones.

\subsection{Sampling Method}

The sample was chosen was from Bengaluru, through multi-stage sampling. The first stage of sample was dividing the sample equally in 10 zones of Bengaluru. In the second stage, random 
sampling and quota was employed to select the respondents, followed by quota sampling, as the questionnaires were equally distributed among men and women. Purposive sampling was also employed and respondents were selected who regularly view cosmetic advertisements and are using cosmetics.

\subsection{Sample Size}

The total population of Bengaluru as per 2011 Census is 96, 21,551. According to B.B.M.P.S.R (Bruhat Bengaluru Mahanagara Palike Statistical Report), the percentage of youth who fall under the category of $15-29$ years is $25.3 \%$. Thus, the total youth population in Bengaluru amounts to $24,34,252$.

\subsection{Data Collection Method}

Primary date was collected using a formal structured questionnaire. Using Standard Questionnaire and Interview schedule was been carried out as an research instrument for data collection because; it is likely to be simple and less expensive procedure, which requires less skill for its administration, it puts less pressure on the respondents for immediate response and provides enough time to the respondent to think and recall, it is free from the bias of the interviewer. The collected data was subjected to various statistical tests such as, regression, correlation, t-test, and ANOVA, quartiles, while the data was also cross-tabulated. The data analysis was carried out using SPSS. Regression and Correlation were used as tools for data analysis.

\subsection{Hypothesis Testing}

\subsubsection{Hypothesis Testing - $\mathrm{H}_{1}$ :}

There is correlation between the Narcissist Personality Factors and Influence of Cosmetic Advertisements

\subsubsection{Hypothesis Testing - $\mathrm{H}_{2}$ :}

There is regression between the Narcissist Personality Factors and Influence of Cosmetic Advertisements.

\section{DATA ANALYSIS AND INTERPRETATION}

\subsection{Demographic Characteristics of the Respondents}

Table 1: Demographic Characteristics

\begin{tabular}{|l|c|c|}
\hline \multicolumn{3}{|c|}{ Demographic Characteristics } \\
\hline Gender & No.of.Respondents & Percentage \\
\hline Male & 250 & 50.0 \\
\hline Female & 250 & 50.0 \\
\hline Total & 500 & 100.0 \\
\hline Educational Qualification & No.of.Respondents & Percentage \\
\hline PUC & 150 & 30.0 \\
\hline Graduation & 200 & 40.0 \\
\hline Post Graduate & 150 & 30.0 \\
\hline Total & $\mathbf{5 0 0}$ & $\mathbf{1 0 0 . 0}$ \\
\hline & & Percentage \\
\hline Family Income & No.of.Respondents & \\
\hline
\end{tabular}


A Study to Assess the Impact of Narcissist Personality Factors in Cosmetic Advertising Among Youth in Bangalore City

\begin{tabular}{|c|c|c|}
\hline$<$ Rs. 25000 & 108 & 21.6 \\
\hline Rs. 25000 to Rs. 50000 & 206 & 41.2 \\
\hline Rs. 50,000 to Rs $1,00,000$ & 112 & 22.4 \\
\hline$>$ Rs. $1,00,000$ & 074 & 14.8 \\
\hline Total & 500 & 100.0 \\
\hline Religion & No.of.Respondents & Percentage \\
\hline Hindu & 167 & 33.4 \\
\hline Muslim & 053 & 10.6 \\
\hline Christian & 273 & 54.6 \\
\hline Others & 002 & 001.4 \\
\hline Total & 500 & 100.0 \\
\hline Mother Tongue & No.of.Respondents & Percentage \\
\hline English & 012 & 002.4 \\
\hline Kannada & 050 & 010.0 \\
\hline Hindi & 020 & 004.0 \\
\hline Urdu & 041 & 008.2 \\
\hline Malayalam & 226 & 045.2 \\
\hline Tamil & 151 & 030.2 \\
\hline Total & 500 & 100.0 \\
\hline Native Place & No.of.Respondents & Percentage \\
\hline Karnataka & 254 & 50.8 \\
\hline Other States & 246 & 49.2 \\
\hline Total & 500 & 100.0 \\
\hline $\begin{array}{l}\text { Money Spent on Purchasing } \\
\text { Cosmetic }\end{array}$ & No.of.Respondents & Percentage \\
\hline I don’t Spent Money & 086 & 017.2 \\
\hline Less than Rs. 500 & 288 & 057.6 \\
\hline Rs. 500 to Rs. 1000 & 101 & 020.2 \\
\hline More than Rs. 1000 & 025 & 005.0 \\
\hline Total & 500 & 100.0 \\
\hline
\end{tabular}

Source: Primary Data

Results in table 1 shows that $50 \%$ of the respondents were male and the other $50 \%$ were female. Under education, $30 \%$ of the respondents are in PUC, $40 \%$ of the respondents are in graduation and the other $30 \%$ are perusing post-graduation. Under family income, Majority of the income of $41.2 \%$ of the families' is between Rs.25,000 and Rs.50,000, the income of $22.4 \%$ of the families' is between Rs. 50,000 and Rs.1, 00,000 and the income of $14.8 \%$ of the respondents is more than Rs. $1,00,000$. Under religion, $33.4 \%$ of the respondents were belongs to Hindus Religion, 10.6\% were belongs to Muslims Religion and $54.6 \%$ were belongs to Christians religion and the remaining $1.4 \%$ belonged to other various religions. Under the language spoken, $2.4 \%$ of the respondents speak English, $10 \%$ speak Kannada, 4\% speak Hindi, $8.2 \%$ speak Urdu, 45.2\% speak Malayalam and the remaining $30.2 \%$ speak Tamil. Under the amount of money spent on purchasing cosmetic products per month, $17.2 \%$ of the respondents do not spend any money on cosmetic products, $57.6 \%$ of the respondents spend around Rs. 500 on purchasing cosmetic products every month, $20.2 \%$ of the respondents spend between Rs.500 to Rs. 1000 per month and 
$5 \%$ of the respondents spend more than Rs. 1000 per month on purchasing cosmetic products.

\subsection{Factor Analysis - Narcissist Personality Factors}

To know the importance of Narcissist Personality Factors that Influence the behaviour of consumers who purchase cosmetic products, factor analysis was performed.

Table 2: KMO and Bartlett's Test

\begin{tabular}{|l|l|c|}
\hline \multicolumn{2}{|c|}{ Kaiser-Meyer-Olkin Measure of Sampling Adequacy. } & $\mathbf{. 6 6 0}$ \\
\hline \multirow{3}{*}{$\begin{array}{l}\text { Bartlett's Test of } \\
\text { Sphericity }\end{array}$} & Approx. Chi-Square & 2519.858 \\
\cline { 2 - 3 } & df & 45 \\
\cline { 2 - 3 } & Sig. & .000 \\
\hline
\end{tabular}

Source: Primary Data

Based on the above output, the KMO $=0.660$. This shows that the degree of common variance is quite high; therefore, factor analysis can be conducted. The Chi-square value of Bartlett's Test of Sphericity is 2519.858 and the significant value is 0.000 , indicating that the data is suitable for factor analysis.

Table 3: Total Variance Explained

\begin{tabular}{|c|c|c|c|c|c|c|c|c|c|}
\hline \multirow[b]{2}{*}{ 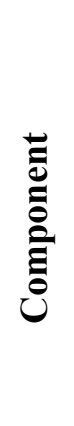 } & \multicolumn{3}{|c|}{ Initial Eigenvalues } & \multicolumn{3}{|c|}{$\begin{array}{l}\text { Extraction Sums of } \\
\text { Squared Loadings }\end{array}$} & \multicolumn{3}{|c|}{$\begin{array}{l}\text { Rotation Sums of } \\
\text { Squared Loadings }\end{array}$} \\
\hline & है & 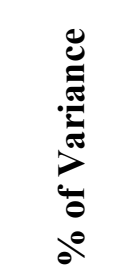 & 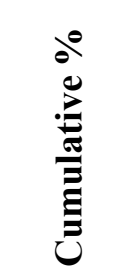 & $\stackrel{\bar{\sigma}}{0}$ & 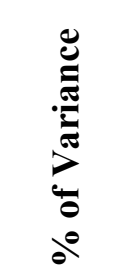 & 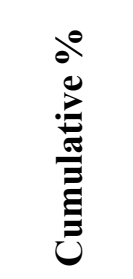 & 跑 & 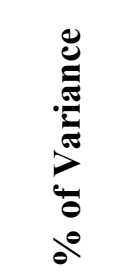 & 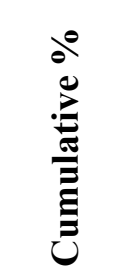 \\
\hline 1 & 3.863 & 38.629 & 38.629 & 3.863 & 38.629 & 38.629 & 3.106 & 31.064 & 31.064 \\
\hline 2 & 1.787 & 17.871 & 56.500 & 1.787 & 17.871 & 56.500 & 2.066 & 20.657 & 51.722 \\
\hline 3 & 1.216 & 12.156 & 68.656 & 1.216 & 12.156 & 68.656 & 1.501 & 15.008 & 66.730 \\
\hline 4 & 1.074 & 10.741 & 79.397 & 1.074 & 10.741 & 79.397 & 1.267 & 12.667 & 79.397 \\
\hline 5 & .639 & 6.388 & 85.785 & & & & & & \\
\hline 6 & .486 & 4.864 & 90.648 & & & & & & \\
\hline 7 & .355 & 3.546 & 94.194 & & & & & & \\
\hline 8 & .270 & 2.703 & 96.897 & & & & & & \\
\hline 9 & .190 & 1.895 & 98.792 & & & & & & \\
\hline 10 & .121 & 1.208 & 100.00 & & & & & & \\
\hline
\end{tabular}

Source: Primary Data

The Rotated Component Matrix indicates, based on factor loadings that these ten components were reduced to four factors. Details of the factors are given in below table.No.04. Rotated Component Matrix. 
A Study to Assess the Impact of Narcissist Personality Factors in Cosmetic Advertising Among Youth in Bangalore City

Table 4: Rotated Component Matrix

\begin{tabular}{|c|c|c|c|c|}
\hline \multirow{2}{*}{ Statements } & \multicolumn{4}{|c|}{ Component } \\
\hline & 1 & 2 & 3 & 4 \\
\hline I want to become fair & .756 & & & \\
\hline Fairness is not important for me & & .770 & & \\
\hline I dream to be like the model who promoted the cosmetic product & & .846 & & \\
\hline I don't want to be like a model who is promoting the cosmetic product & .815 & & & \\
\hline I only use the mirror to comb my hair & & .814 & & \\
\hline I spend some time to admire myself in front of the mirror & & & .606 & \\
\hline My confidence level does not increase by using cosmetic products & .784 & & & \\
\hline Cosmetic products give me confidence & & & .913 & \\
\hline Cosmetic products have become an integral part of my life & & & & .914 \\
\hline I don't depend upon cosmetic products & .847 & & & \\
\hline
\end{tabular}

Source: Primary Data

Table 5: List of Factors

\begin{tabular}{|c|c|c|c|c|}
\hline Sl.No. & Component & TVE & Variable & RCMV \\
\hline \multirow{4}{*}{1} & \multirow{4}{*}{ Fairness } & \multirow{4}{*}{38.629} & 1. I want to become fair & .756 \\
\hline & & & $\begin{array}{l}\text { 4. I don't want to be like a model who is } \\
\text { promoting the cosmetic product }\end{array}$ & .815 \\
\hline & & & $\begin{array}{l}\text { 7.My confidence level does not increase by } \\
\text { using cosmetic products }\end{array}$ & .784 \\
\hline & & & 10. I don't depend upon cosmetic products & .847 \\
\hline \multirow{3}{*}{2} & \multirow{3}{*}{$\begin{array}{l}\text { Imitating } \\
\text { Models }\end{array}$} & \multirow{3}{*}{17.871} & 2. Fairness is not important for me & .847 \\
\hline & & & $\begin{array}{l}\text { 3. I dream to be like the model who promoted } \\
\text { the cosmetic product }\end{array}$ & .846 \\
\hline & & & 5. I only use the mirror to comb my hair & .814 \\
\hline \multirow[t]{2}{*}{3} & \multirow[t]{2}{*}{ Loving Oneself } & \multirow[t]{2}{*}{12.156} & $\begin{array}{l}\text { 6. I spend some time to admire myself in front } \\
\text { of the mirror }\end{array}$ & .606 \\
\hline & & & 8. Cosmetic products give me confidence & .913 \\
\hline 4 & $\begin{array}{l}\text { Importance to } \\
\text { Cosmetics }\end{array}$ & 10.741 & $\begin{array}{l}\text { 9. Cosmetic products has become an integral } \\
\text { part of my life }\end{array}$ & .914 \\
\hline
\end{tabular}

Source: Primary Data

\subsubsection{Factor - 01. Fairness}

This factor alone contributes to $38.6 \%$ of the total variance. Respondents want to be fair and they also feel that using cosmetic products give them confidence. They do not want to look like the models who are promoting the cosmetic products and they also feel that they do not depend on cosmetic products.

\subsubsection{Factor - 02. Imitating Models}

The factor alone contributes to $17.8 \%$ of the total variance. Fairness is not important for the respondents. They dream of becoming like the model who is promoting the cosmetic product. They spend a decent amount of time in front of the mirror admiring them.

\subsubsection{Factor - 03. Loving Oneself}

The factor alone contributes to $12.1 \%$ of the total variance. The respondents only use the mirror to come their hair and their confidence level does not increase when they use cosmetic products. 


\subsubsection{Factor - 04. Importance to Cosmetics}

The factor alone contributes to $10.7 \%$ of the total variance. The respondents feel that the cosmetic products have become an integral part of their lives.

\subsection{Correlations Analysis}

The researcher performed the suitable and appropriate analysis to find out the relationship between the dependent variable 'Influence of Cosmetic Advertisements' and the independent variables derived from Narcissist Personality. This Correlation analysis will infer the relevance and importance of study by analyzing the relation between the various study variables. This Correlation Analysis was performed to know significant relationship among all the variables. The correlation table indicates the correlation analysis is significant at 0.01 confident level.

Table 6: Correlations Analysis

\begin{tabular}{|c|c|c|c|c|c|c|}
\hline Cor & elation Analysis & $\begin{array}{l}\frac{n}{2} \\
\frac{0}{0} \\
\frac{0}{0}\end{array}$ & $\stackrel{\mathscr{E}}{\stackrel{0}{E}}$ & $\begin{array}{l}\frac{n}{0} \\
\sum_{0.0}^{0} \\
.0\end{array}$ & 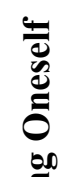 & 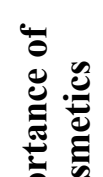 \\
\hline & Pearson Correlation & 1 & & & & \\
\hline Inmuence & Sig. (2-tailed) & & & & & \\
\hline & $\mathrm{N}$ & 500 & & & & \\
\hline & Pearson Correlation & $.201^{* *}$ & 1 & & & \\
\hline Fairness & Sig. (2-tailed) & .000 & & & & \\
\hline & $\mathrm{N}$ & 500 & 500 & & & \\
\hline & Pearson Correlation & .079 & $.330^{* *}$ & 1 & & \\
\hline $\begin{array}{l}\text { Imitating } \\
\text { Models }\end{array}$ & Sig. (2-tailed) & .079 & .000 & & & \\
\hline & $\mathrm{N}$ & 500 & 500 & 500 & & \\
\hline & Pearson Correlation & $809^{* *}$ & $.490^{* *}$ & $.232^{* *}$ & 1 & \\
\hline $\begin{array}{l}\text { Loving } \\
\text { Oneself }\end{array}$ & Sig. (2-tailed) & .000 & .000 & .000 & & \\
\hline & $\mathrm{N}$ & 500 & 500 & 500 & 500 & \\
\hline Importance & Pearson Correlation & $.160^{* *}$ & $.203^{* *}$ & $.156^{* *}$ & .052 & 1 \\
\hline & Sig. (2-tailed) & .000 & .000 & .000 & .246 & \\
\hline Cosmetics & $\mathrm{N}$ & 500 & 500 & 500 & 500 & 500 \\
\hline
\end{tabular}

There is a positive and strong correlation between those dependent factors variable 'Influence of Cosmetic Advertisements' and three independent factors. It was found that influence of advertisements had a positive correlation with 'fairness' $(r=0.201)$, 'loving oneself' $(r=0.809)$ and 'importance to cosmetics' $(r=0.160)$. Here the researcher would like to infer that there is a strong inter-correlation exists among the independent variables and also it is been found that most of them are positively correlated with each other variables. Further the researcher would like to clarify that that 'fairness' is strongly correlated with 'Imitating Models' $(\mathrm{r}=0.330)$, 'fairness' is positively correlated with 'Imitating Models' $(\mathrm{r}=0.490)$, 'Imitating Models' is positively correlated with 'loving oneself $(r=0.232)$, 'fairness' is positively correlated with 'importance to cosmetics' ( $\mathrm{r}=0.203)$ and 'Imitating Models' is positively correlated with 'importance to cosmetics' $(r=0.156)$. As most of the independent 
A Study to Assess the Impact of Narcissist Personality Factors in Cosmetic Advertising Among Youth in Bangalore City

variables are showing high correlation with the dependent variable, Therefore the researcher rejected the null hypothesis $\left(\mathrm{H}_{0}\right)$ and wherein accepted the alternative hypothesis $\left(\mathrm{H}_{\mathrm{A}}\right)$. Thus, there is a correlation between the Narcissist Personality Factors and Influence of Cosmetic Advertisements.

\subsection{Regression Analysis}

Here the researcher performed the suitable and appropriate analysis in order to identify the major impact of 'Narcissist Personality Factors' on that of these 'Influence of Cosmetic Advertisements'. In the regression analysis 'Influence of Cosmetic Advertisements' were the dependent factor variable and the independent factor variables were fairness, imitating models, loving oneself and importance to cosmetics. These 4 narcissist major personality variables, which were concentrated as the major independent factors or variables, which were needs to be used to test if the cosmetic advertisements influence the consumers.

Table 7: Analysis of Variance of Influence Cosmetic Advertisements on Consumers

\begin{tabular}{|c|l|c|c|c|c|c|}
\hline \multicolumn{2}{|c|}{ Model } & Sum of Squares & df & Mean Square & F & Sig. \\
\hline \multirow{4}{*}{1} & Regression & 353.448 & 4 & 88.362 & 348.380 & $.000^{\mathrm{a}}$ \\
\cline { 2 - 7 } & Residual & 125.550 & 495 & .254 & & \\
\cline { 2 - 7 } & Total & 478.998 & 499 & & & \\
\hline
\end{tabular}

Source: Primary Data

From the Table.No.07, it is been clearly inferred that, the core research model been applied to the most extent and it would be more enough to identify the influence of cosmetic advertisements on consumers.

Table 8: Model Summary of Influence Cosmetic Advertisements on Consumers

\begin{tabular}{|c|c|c|c|c|}
\hline Model & R & R Square & Adjusted R Square & Std. Error of the Estimate \\
\hline 1 & $.859^{\mathrm{a}}$ & .738 & .736 & .504 \\
\hline
\end{tabular}

Source: Primary Data

From the Table.No.08, it is been clearly inferred that there are totally four predictors of influence of cosmetic advertisement (the independent variables such as fairness, imitating models, loving oneself, and importance to cosmetics) represent $85.9 \%$ if the variance. It means that $85.9 \%$ of the influence of cosmetic advertisements has more impact by various independent variable factors, while the remaining may also has similar lesser impact be due to other major variable factors involved in it.

Table 9: Coefficients of Regression of Influence Cosmetic Advertisements on Consumers

\begin{tabular}{|c|c|c|c|c|c|c|}
\hline & \multirow[t]{2}{*}{ Model } & \multicolumn{2}{|c|}{$\begin{array}{c}\text { Unstandardized } \\
\text { Coefficients } \\
\end{array}$} & \multirow{2}{*}{$\begin{array}{c}\text { Standardized } \\
\text { Coefficients } \\
\text { Beta } \\
\end{array}$} & \multirow[t]{2}{*}{$\mathbf{t}$} & \multirow[t]{2}{*}{ Sig. } \\
\hline & & B & Std. Error & & & \\
\hline \multirow{5}{*}{1} & (Constant) & .265 & .179 & & 1.483 & .139 \\
\hline & Fairness & -.342 & .034 & -.276 & -9.962 & .000 \\
\hline & Imitating Models & -.092 & .028 & -.080 & -3.239 & .001 \\
\hline & Loving Oneself & 1.076 & .030 & .953 & 35.909 & .000 \\
\hline & Importance of Cosmetics & .311 & .041 & .179 & 7.555 & .000 \\
\hline
\end{tabular}

Source: Primary Data 
From the Table.No.09, it is been clearly inferred that there was a strong relation of 'Influence of Cosmetic Advertisements' with four independent variables $(95 \%$ level of confidence). Fairness has the 'p' value of 0.00 , loving oneself has the ' $p$ ' value of 0.01 , no importance to cosmetics has a ' $p$ ' value of 0.00 and importance to cosmetics has a ' $p$ ' value of 0.00 . Hence the four independent factors, fairness, imitating models, loving oneself and importance to cosmetics have an impact on cosmetic advertisements.

The Standard Regression Equation: $\mathbf{Y}=\mathbf{a}+\mathbf{b}_{1} \mathbf{X}_{\mathbf{1}}+\mathbf{b}_{2} \mathbf{X}_{\mathbf{2}}+\mathbf{b}_{3} \mathbf{X}_{3} \ldots+\mathbf{b}_{\mathbf{n}} \mathbf{X}_{\mathbf{n}}+$

\section{' $Y$ ' $=$ Dependent Variable - (Consumer Purchase Intentions) \\ $a=0.265$ (constant), $b_{1}=-0.342, b_{2}=-0.092, b_{3}=1.076, b_{4}=0.311$}

In the above table, 'Loving Oneself' has the highest coefficient value of 1.076, so loving oneself has the highest impact on 'Influence of Cosmetic Advertisements'.

\section{The regression equation is given by:}

\section{Regression Equation $=$ Influence of cosmetic advertisement $=0.265-0.342$ (Fairness) \\ - 0.342 (Imitating Models) + 1.076 (Loving Oneself) + 0.311 (Importance of \\ Cosmetics) +0.504}

As the value of significance is less than the expected value of 0.05 , Therefore the researcher rejected the null hypothesis $\left(\mathrm{H}_{0}\right)$ and wherein accepted the alternative hypothesis $\left(\mathrm{H}_{\mathrm{A}}\right)$. Hence, the researcher would like to conclude that there is regression between the Narcissist Personality Factors and Influence of Cosmetic Advertisements.

\section{FINDINGS AND CONCLUSION}

With the help of factor analysis, four factors were identified from the first independent variable which is 'Narcissist Personality Factors'; the four factors are 'Fairness', 'Imitating Models', 'Loving Oneself' and 'Importance to Cosmetics'. From the study it was found that women spend more money on cosmetic product when compared to men. The students who are perusing their graduation spend more money on cosmetic products, followed by the students who are perusing there plus two and post-graduation. The study was also able to find out that families with income more than Rs. 1,00,000 spend the highest amount of money on cosmetic products among various categories. Among various religions, Hindus spend highest amount of money purchasing cosmetic products, followed by Christians and Muslims. The respondents who speak English spend the highest among of money purchasing cosmetic products, followed by Kannada, Hindi, Tamil, Malayalam and Urdu. From the regression analysis it was shown that 'Loving Oneself' has the highest impact on Consumer Behaviour.

The first hypothesis was based on the dependent variable 'Influence of Cosmetic Advertisements' and the factors of Narcissist Personality. The dependent variables factors have shown a positive and strong correlation with all major aspects of personality. The second hypothesis was based on the dependent variable 'Influence of Cosmetic Advertisements' and the factors of Narcissist Personality. The dependent variables have shown a positive regression with Narcissist Personality. From the study it can be learnt that the cosmetic advertisements have a very strong impact on the personality of the individual. This it is very much necessary for the cosmetic companies to be very careful when they are advertising their products. As a result, these advertisements had created a wrong impression and it certainly affected the overall personality of the consumers. From the study it can be learnt that, it is not only women who 
A Study to Assess the Impact of Narcissist Personality Factors in Cosmetic Advertising Among Youth in Bangalore City

spend a lot of money on cosmetics but also men do spend a lot of money in buying cosmetic products.

There is definitely scope for further research. Further research on topic can focus on how the Narcissist Personality, Necrophilia Personality and Sadistic Personality have an impact on a consumer's overall personality. Studies can also strive to identify various other factors under Narcissist Personality, Necrophilia Personality and Sadistic Personality. The studies should also try to understand the impact of 'Mother Tongue' and the 'Amount of Money Spent' on consumer's behaviour and his choice. The study has taken all products into consideration, but further research can target single cosmetic products as it will help the research to do much indepth research into the subject.

\section{REFERENCE}

[1] Dhadhal, Chitralekha H. (2011) A Study of Brand Loyalty and its Effect on Buying Behaviour In Case of Selected Cosmetics Products in the State of Gujarat. PhD thesis, Saurashtra University.

[2] Kuhn, T. S. (1962). The Structure of Scientific Revolutions. Chicago. Chicago University Press.

[3] Edward Chamberlain (1933), "The Theory of Monopolistic Competition", The American Economic Review, Vol.No.23, Issue.No.04, Dec., 1933, pp. 683-685, 1933.

[4] Taylor, Lester D. and Daniel, Weiserbs (1972), "Advertising and Aggregate Consumption Function”, The American Economic Review, Vol.No.12, Issue.No.04, pp.642-55, 1972.

[5] Shimp, T. A. (1981), "Attitude toward the ad as a mediator of consumer brand choice". Journal of Advertising, Vol.No.10, Issue.No.02, pp.09-48, 1981.

[6] Bloch, Peter \& Richins, Marsha. (1992), "You Look "Mahvelous": The Pursuit of Beauty and the Marketing Concept", Psychology and Marketing, 1992. Vol.09, pp. 03 - 15. https://doi.org/10.1002/mar.4220090103.

[7] Ashesh Mukherjee, Wayne D. Hoyer (2001), The Effect of Novel Attributes on Product Evaluation, Journal of Consumer Research, Volume 28, Issue 3, December 2001, 462-472, https://doi.org/10.1086/323733

[8] Shallu, Sangeeta Gupta (2013), "Impact of Promotional Activities on Consumer Buying Behavior: A Study of Cosmetic Industry", IRACST - International Journal of Commerce, Business and Management (IJCBM), Vol.No.02, Issue.No.06, December 2013.

[9] Sumathi, Mustiary Begum (2016), "Impact Of Advertisements on Consumer Behaviour of Cosmetic Products -A Study in Mangalore", International Journal of Scientific Research and Modern Education (IJSRME), Vol.No.01, Issue.No.01, 2016.

[10] Anjana S.S (2018), "A Study on Factors Influencing Cosmetic Buying Behavior of Consumers", International Journal of Pure and Applied Mathematics, Vol.No.118, Issue.No.19, pp.453-459, 2018.ue.No.19, pp.453-459, 2018. 